\title{
Activation of NF- $\kappa$ B in Schwann Cells Is Dispensable for Myelination In Vivo
}

\author{
Paul D. Morton, ${ }^{1,2}$ Anna Dellarole, ${ }^{1,2}$ Michelle H. Theus, ${ }^{3}$ Winston M. Walters, ${ }^{1,2}$ Summer S. Berge, ${ }^{1}$ \\ and John R. Bethea ${ }^{1,2,4}$ \\ ${ }^{1}$ The Miami Project To Cure Paralysis, Miller School of Medicine, University of Miami, Miami, Florida 33136, ${ }^{2}$ Department of Neurosurgery, Miller School \\ of Medicine, University of Miami, Miami, Florida 33136, ${ }^{3}$ Department of Biomedical Sciences and Pathobiology, Virginia-Maryland Regional College of \\ Veterinary Medicine, Blacksburg, Virginia 24061, and ${ }^{4}$ Department of Microbiology and Immunology, Miller School of Medicine, University of Miami, \\ Miami, Florida 33136
}

Peripheral myelination is a dynamic process orchestrated by axons and Schwann cells. Although the signaling mechanisms governing myelination are not fully understood, NF- $\kappa \mathrm{B}$ activation in Schwann cells has been implicated as a key regulator in vitro. Using a mouse model, we show that nuclear factor $\kappa \mathrm{B}$ activation in Schwann cells is not required for myelination in vivo.

\section{Introduction}

The nuclear factor $\kappa \mathrm{B}(\mathrm{NF}-\kappa \mathrm{B})$ transcription factor regulates many physiological processes and requires $\mathrm{I} \kappa \mathrm{B}$ kinase $\beta(\mathrm{IKK} \beta)$ for activation ( $\mathrm{Li}$ et al., 1999). Commencing at birth, largediameter axons within peripheral nerves are myelinated by Schwann cells (SCs); SC precursors arise during gestation (embryonic day 12-13) and can be identified by their expression of myelin protein zero (MPZ) (Jessen and Mirsky, 2005). Previous studies have shown that NF- $\kappa \mathrm{B}$ signaling in SCs is required for SC differentiation and myelin induction in vitro; however, these findings have not been verified in vivo (Nickols et al., 2003; Yoon et al., 2008; Limpert and Carter, 2010; Chen et al., 2011; Limpert et al., 2013). Here, we show that NF- $\kappa \mathrm{B}$ activation in SCs is dispensable for myelination in vivo.

\section{Materials and Methods}

Animals. All animals were generated and housed in a virus/antigen-free facility with a $12 \mathrm{~h}$ light/dark cycle; food and water ad libitum. Genotyping of tail DNA was performed as previously described (Li et al., 2003). The following primers were used: 5'-GTC ATT TCC ACA GCC CTG TGA-3' and $5^{\prime}$-CCT TGT CCT ATA GAA GCA CAA C-3' to amplify both IKK $\beta^{\mathrm{f}}$ and IKK $\beta^{+}$alleles; $5^{\prime}$-ACG AAC CTG GTC GAA ATC AGT GCG-3' and 5' -CGG TCG ATG CAA CGA GTG ATG AG-3' to amplify Cre.

Received May 23, 2012; revised April 29, 2013; accepted May 2, 2013.

Author contributions: P.D.M. and J.R.B. designed research; P.D.M., A.D., M.H.T., W.M.W., and S.S.B. performed research; P.D.M. analyzed data; P.D.M. wrote the paper.

This work was supported by the National Institutes of Health (NS051709, NS065479 to J.R.B.) and The Miami Project to Cure Paralysis. We thank M. Karin (University of California, San Diego) for providing the IKK $\beta^{\mathrm{f} / \mathrm{f}}$ mice and J. Milbrandt (Washington University, School of Medicine) for providing the MPZ-Cre mice. We also thank M. Bates for EM sample preparation at the University of Miami EM core facility.

The authors declare no competing financial interests.

Correspondence should be addressed to Dr. John R. Bethea, The Miami Project to Cure Paralysis, Departments of Neurosurgery, Microbiology and Immunology, Miller School of Medicine, 1095 NW 14th Terrace, Lois Pope Life Center 3-21, Miami, FL 33136. E-mail: jbethea@med.miami.edu.

P.D. Morton's present address: Center for Neuroscience Research, Children's National Medical Center, Washington, $D C 20010$.

DOI:10.1523/JNEUROSCI.2483-12.2013

Copyright $\odot 2013$ the authors $\quad 0270-6474 / 13 / 339932-05 \$ 15.00 / 0$
Sciatic nerve crush injury. Adult, male mice were anesthetized with ketamine/xylazine (University of Miami, Division of Veterinary Resources, Miami, FL). The right sciatic nerve was exposed and crushed at the level of the midthigh until transparent, using uniformly ground microforceps. Animals were killed $1 \mathrm{~d}$ following injury.

Schwann cell isolation. Adult Schwann cells were isolated from sciatic nerves of adult, male mice as previously described (Manent et al., 2003). Briefly, both sciatic nerves were removed from 2-4-month-old mice in sterile conditions. Twelve nerves were pooled per experiment and incubated in a pretreatment medium, replaced every $2 \mathrm{~d}$, for $7 \mathrm{~d}$ to enable Wallerian degeneration. Nerves were then incubated in an enzymatic medium and mechanically dissociated through a narrowed Pasteur pipette. Following centrifugation, cells were resuspended in N2 ${ }^{\mathrm{HRG}}$ medium and plated on wells coated with poly-L-lysine and laminin. Nonadhesive cells were replated $24 \mathrm{~h}$ later. Cells were kept in culture at $37^{\circ} \mathrm{C}, 7 \% \mathrm{CO}_{2}$ until confluent. Perinatal Schwann cells were isolated from sciatic nerves of mice at 8 or $12 \mathrm{~d}$ of age, as previously described (Honkanen et al., 2007). Briefly, both sciatic nerves were dissected out from each animal and pooled together. Connective tissue was removed and the clean nerves were shredded with microforceps. Nerves were enzymatically digested in trypsin and collagenase for $30 \mathrm{~min}$ at $37^{\circ} \mathrm{C}$. Cells were plated on poly-L-lysine-coated culture dishes in Schwann cell growth medium (high-glucose DMEM with 10\% inactivated horse serum, $4 \mathrm{~mm}$ L-glutamine, $1 \times$ penicillin/streptomycin (Invitrogen), $2 \mathrm{ng} / \mathrm{ml}$ human heregulin- $\beta 1,0.5 \mu \mathrm{M}$ forskolin, $10 \mathrm{ng} / \mathrm{ml}$ human basic fibroblast growth factor, and $20 \mu \mathrm{g} / \mathrm{ml}$ bovine pituitary extract) at $37^{\circ} \mathrm{C}, 7 \% \mathrm{CO}_{2}$ for $4 \mathrm{~d}$.

Schwann cell quantification. Following $4 \mathrm{~d}$ of incubation, Schwann cell cultures were fixed with $4 \%$ PFA in PBS for 20 min and stained with a rabbit antibody against $S 100 \beta$ (1:5000; DAKO) along with a tyramide signal amplification kit (TSA), with HRP-goat anti-rabbit IgG (Invitrogen). Cells were then stained with a rabbit antibody against p65, phosphoSer276 (1:400; Millipore) followed by anti-rabbit Alexa Fluor 594 (1:750; Invitrogen). Images were obtained at $10 \times$. The total number of $\mathrm{S} 100 \beta^{+}$and $\mathrm{S} 100 \beta^{+}(\mathrm{p})-\mathrm{p} 65^{+}$cells were counted from three random fields per animal per group.

Generation of MPZ-CreIKK $\beta^{-1-}$ mice. MPZ-CreIKK $\beta^{-1-}$ mice were generated by crossing MPZ-Cre females (a kind gift from Dr. Jeffrey Milbrandt, Washington University, St. Louis, MO) (Ryu et al., 2007) with IKK $\beta^{\mathrm{F} / \mathrm{F}}$ males (generously donated by Dr. Michael Karin, Univer- 
A

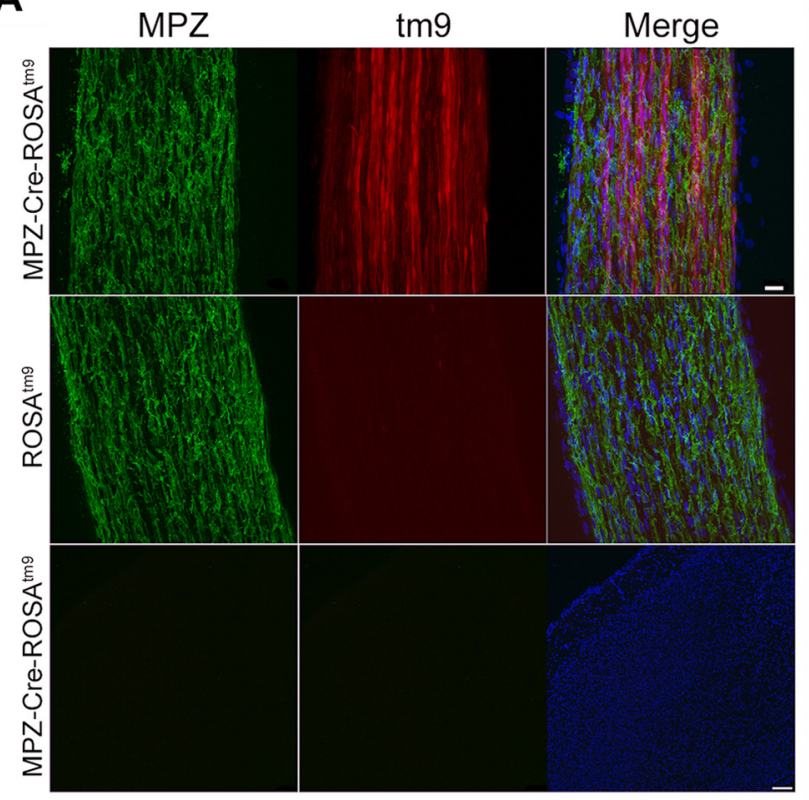

B

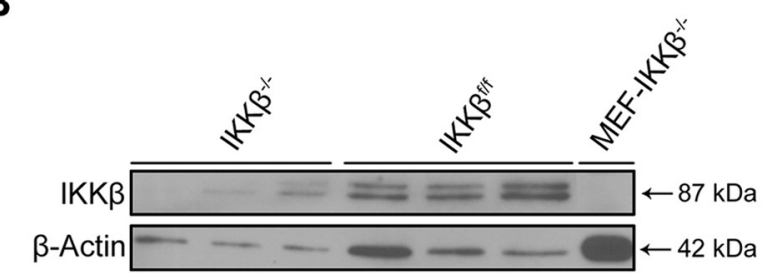

C

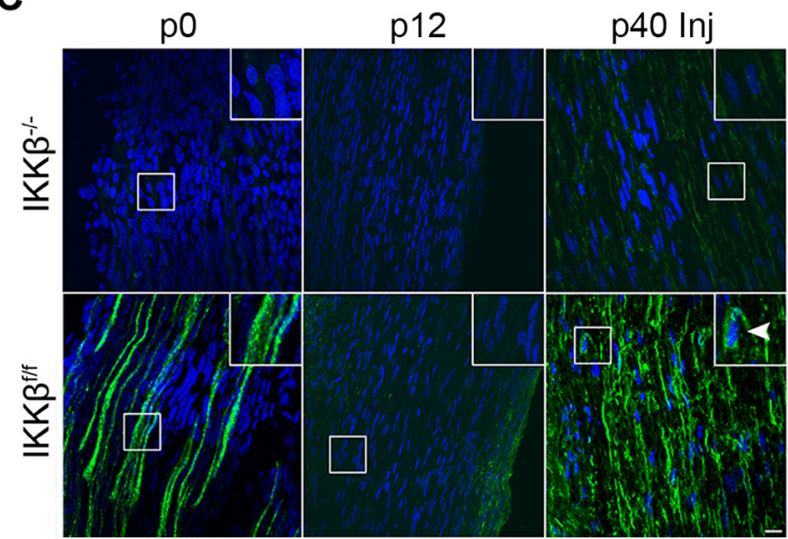

D

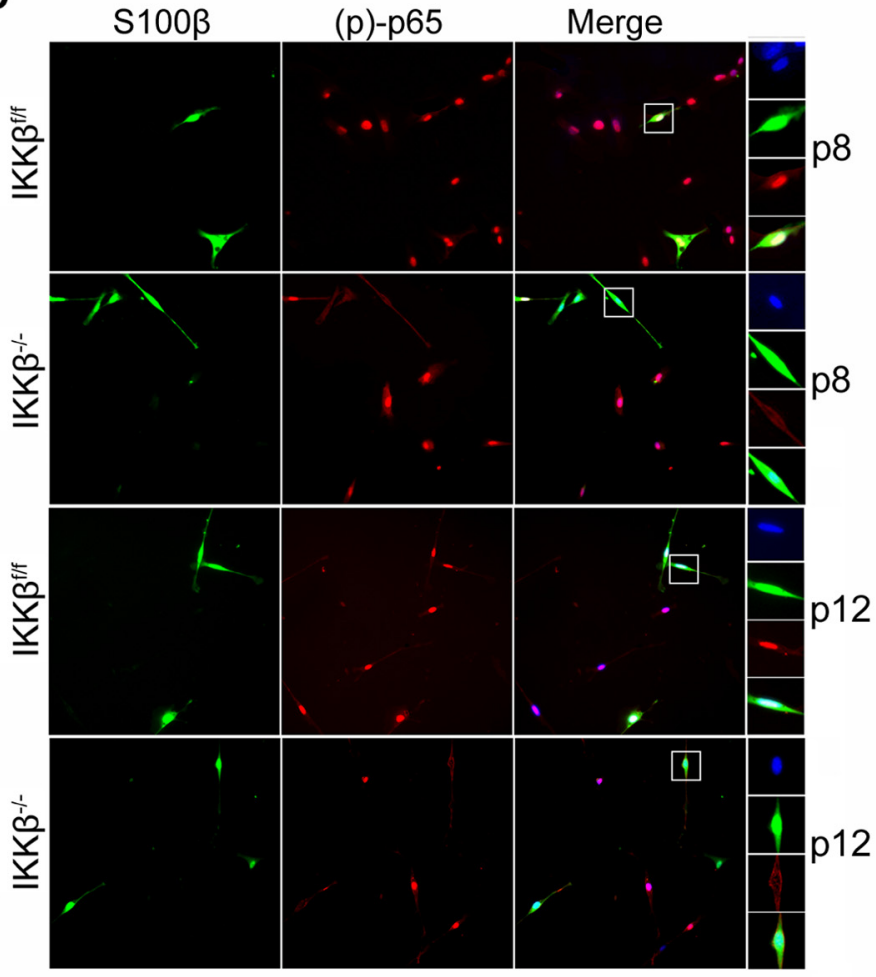

E

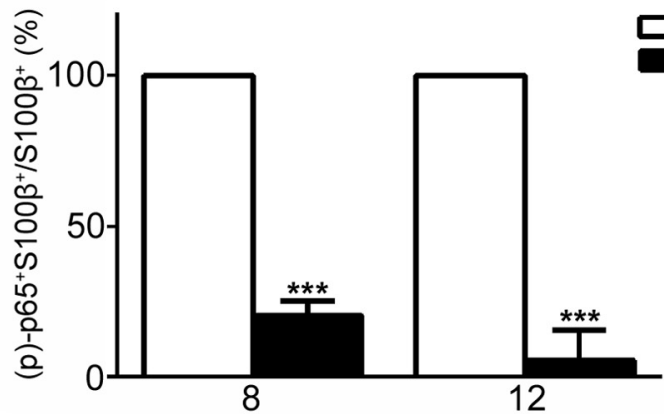

Figure 1. Characterization of IKK $\beta^{-/-}$mice. A, MPZ-Cre-ROSA ${ }^{\mathrm{tm} 9}$ heterozygotes and ROSA ${ }^{\mathrm{tm} 9}$ reporter mice. MPZ immunofluorescence (green) in longitudinal sections of sciatic nerves (top, middle) and transverse sections of cortex (bottom) at p15. Cre recombination, driven by the MPZ promoter, can be seen in the sciatic nerve but not the cortex. DAPI (blue) illuminates cell nuclei. tm6, tomato 6. Scale bars: top, $20 \mu \mathrm{m}$; bottom, $100 \mu \mathrm{m} . n=3$ animals per group. $B$, Immunoblot for IKK $\beta$ and loading control ( $\beta$-actin) on Schwann cell cultures isolated from adult sciatic nerves. MEF-IKK $\beta^{-l-}$ cells serve as a negative control. $n=3$ groups (pooled nerves from 6 animals) per well. MEF, mouse embryonic fibroblast. $C$, Immunostains of p-p65 (green) and DAPI (blue) in naive sciatic nerves at $\mathrm{p} 0$ and p12), and injured (Inj) adult (p40) sciatic nerves, $1 \mathrm{~d}$ following injury (1 dpi). Robust p-p65 expression can be seen in naive p0 and injured (1dpi) adult IKK $\beta^{\mathrm{f} / \mathrm{f}}$ (white arrowheads) but not IKK $\beta^{-1-}$ sciatic nerves. p-p65 Immunoreactivity appears to be absent in p12 sciatic nerves in both groups. Scale bar, $20 \mu \mathrm{m}$. D, Immunostains of S100 $\beta$ (green) and p-p65 (red) in Schwann cell cultures isolated from perinatal sciatic nerves at p8 and p12. Insets show nuclear colocalization (DAPI, blue) of activated p65 in S100 $\beta^{+}$Schwann cells. $\boldsymbol{E}$, Images were obtained on the fourth day in vitro. Quantification of $S 100 \beta^{+} \mathrm{p}-\mathrm{p} 65^{+}$double-positive cells $(\boldsymbol{D})$, harvested from $\mathrm{p} 8$ and p12 sciatic nerves, expressed as a percentage of the total number of $\mathrm{S} 100 \beta^{+}$Schwann cells. All Schwann cells from IKK $\beta^{\mathrm{f} / \mathrm{f}}$ nerves expressed activated $\mathrm{p} 65$. Data are expressed as the mean \pm SEM of 3 animals $/ \mathrm{group} .{ }^{* * *} p<0.0001$, unpaired Student's $t$ test $\left(I K K \beta^{-I-}\right.$ vs IKK $\left.\beta^{\mathrm{f} / f}\right)$.

sity of California San Diego, La Jolla, CA), which have a floxed $1.65 \mathrm{~kb}$ fragment of IKK $\beta$ flanking exon 3, on a C57BL/6 background (Li et al., 2003). MPZ-CreIKK $\beta^{+/-}$and IKK $\beta^{\mathrm{F} / \mathrm{F}}$ progeny were bred to generate MPZ-CreIKK $\beta^{-1-}$ mice lacking the third exon of IKK $\beta$, which codes for the ATP binding site of the kinase domain. No overt behavioral pheno- types were observed in homozygotes throughout adulthood ( $\leq 2$ years of age). Animals were housed on a $12 \mathrm{~h}$ light/dark cycle in a virus/antigenfree facility with food and water ad libitum.

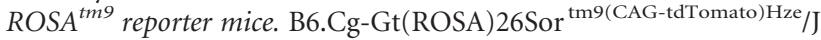
$\left(\right.$ ROSA $^{\mathrm{tm} 9}$ ) homozygous mice were obtained from The Jackson Labora- 
A

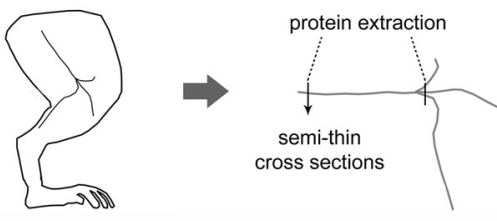

C

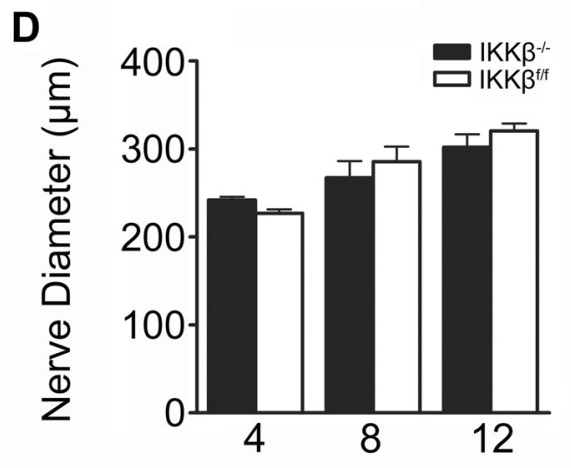

B

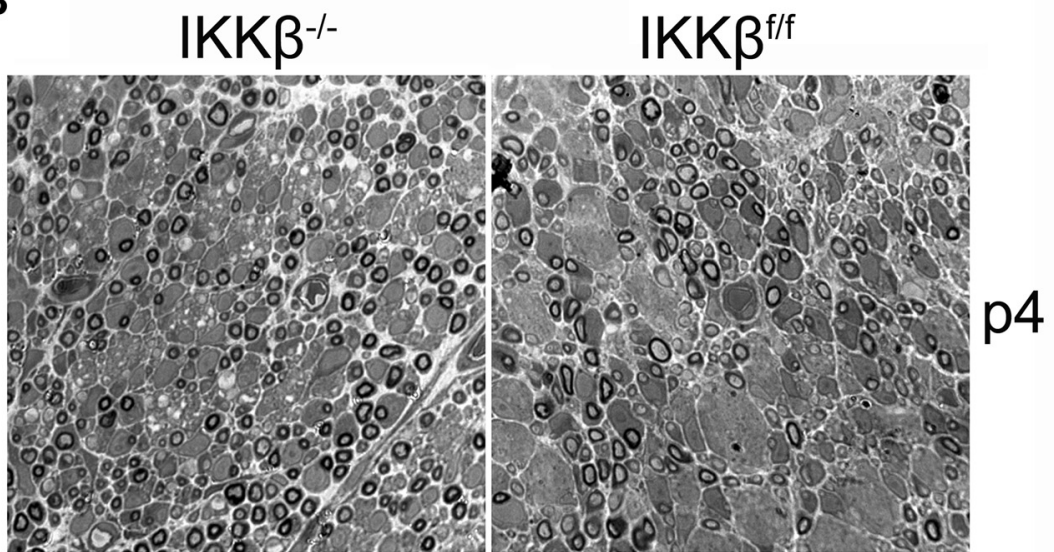

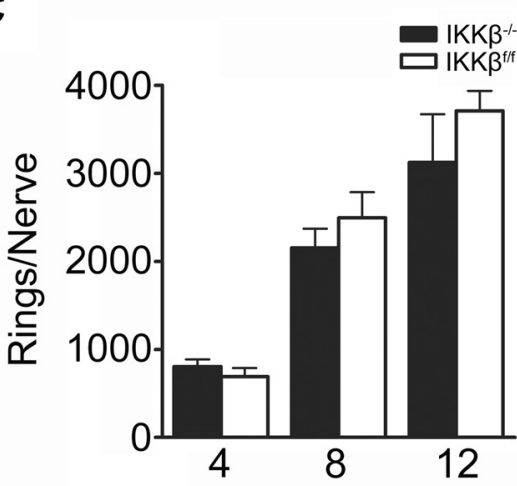

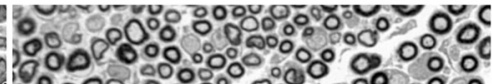

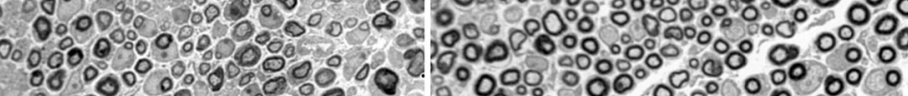

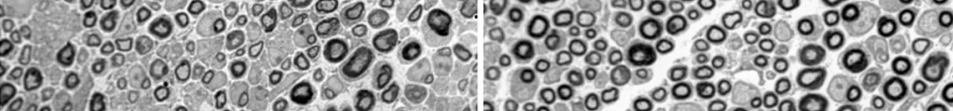

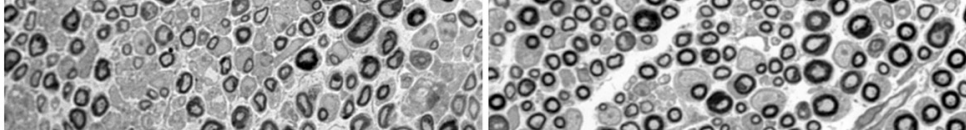

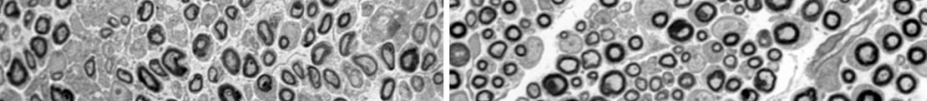

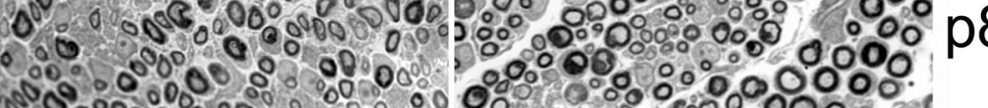

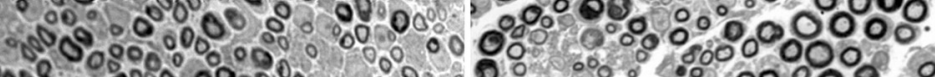

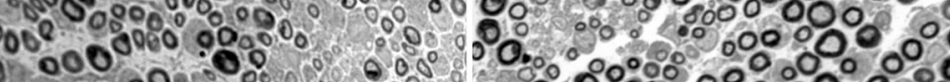

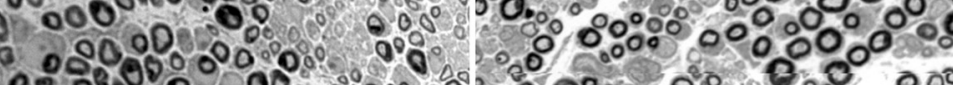

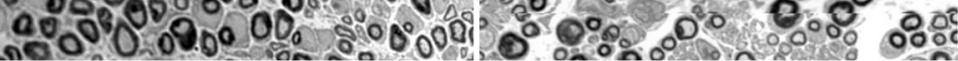

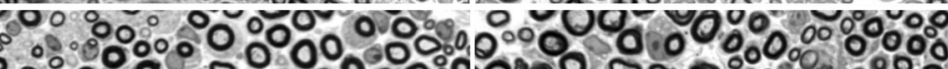

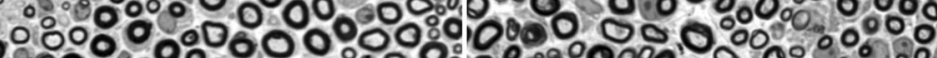

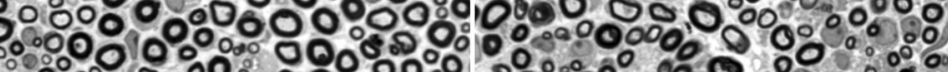

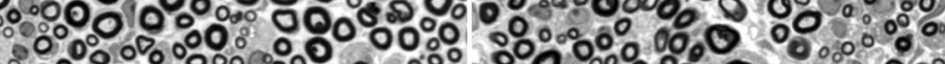

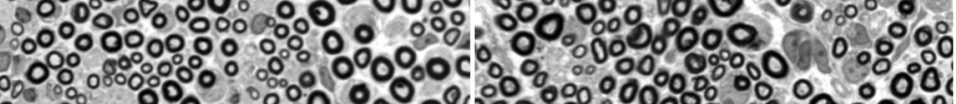

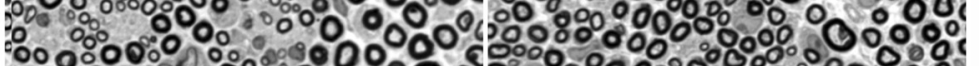

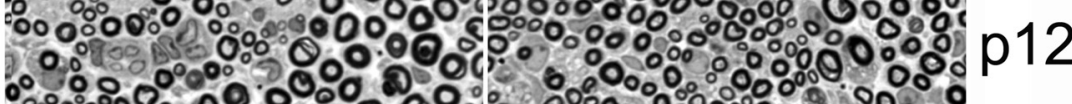

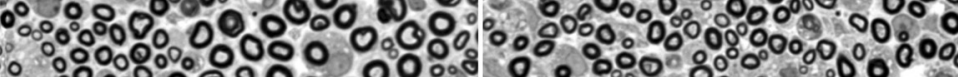

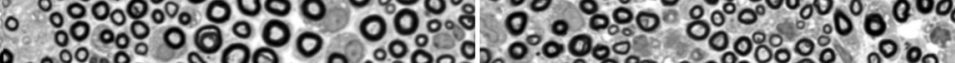

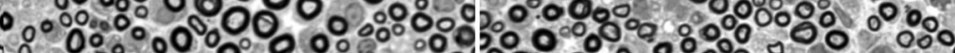

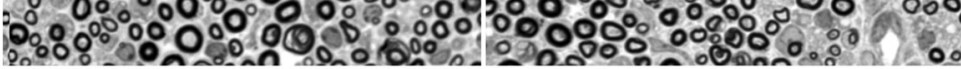

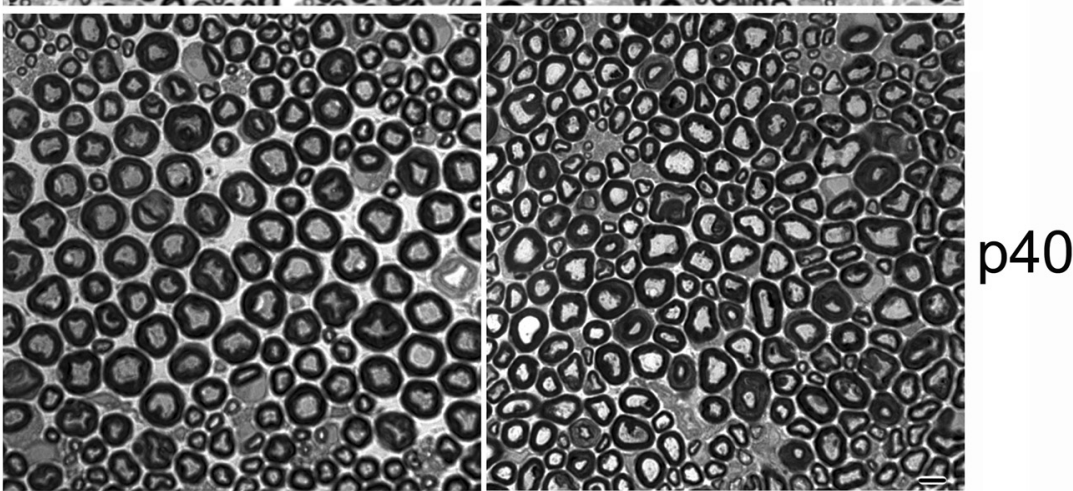

Figure 2. Morphometric assessment of perinatal, sciatic nerve development. $A$, Schematic of sciatic nerve dissection. $B$, Transverse, semithin sections of perinatal sciatic nerves stained with PPD and TB at p4, p8, p12, and p40. Scale bar, $5 \mu \mathrm{m}$. C, D, Quantification of sciatic nerve diameter ( $\boldsymbol{C}$ and total number of myelin rings at p4, p8, and p12 (D). Data were obtained from PPD-stained sections and are expressed as the mean \pm SEM of $3-5$ animals/group. ${ }^{*} p<0.05$, unpaired Student's $t$ test (IKK $\beta^{-/-}$vs IKK $\left.\beta^{\mathrm{f} / \mathrm{f}}\right)$.

tory and crossed with WT or MPZ-CreIKK $\beta^{-1-}$ mice to determine promoter specificity and Cre efficacy. ROSA ${ }^{\mathrm{tm} 9}$ mice possess a loxPflanked STOP cassette upstream of tdTomato (a red fluorescent protein variant). Upon Cre-recombination, tdTomato is expressed in the cre-expressing tissue.
Immunohistochemistry. Following transcardial perfusion with $4 \%$ p-formaldehyde in $0.1 \mathrm{~mol} / \mathrm{l} \mathrm{PBS}$, sciatic nerves were removed and postfixed for $1 \mathrm{~h}$. Nerves were cryoprotected in $0.1 \mathrm{~mol} / \mathrm{l} \mathrm{PBS}$ containing 20\% sucrose. Longitudinal sections were cut at $16 \mu \mathrm{m}$, incubated overnight at $4^{\circ} \mathrm{C}$ with a chicken antibody against MPZ (1:100; Abcam) 
A

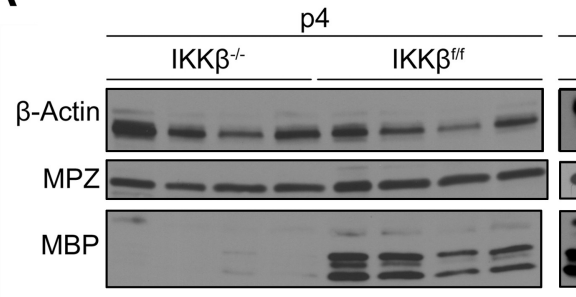

B
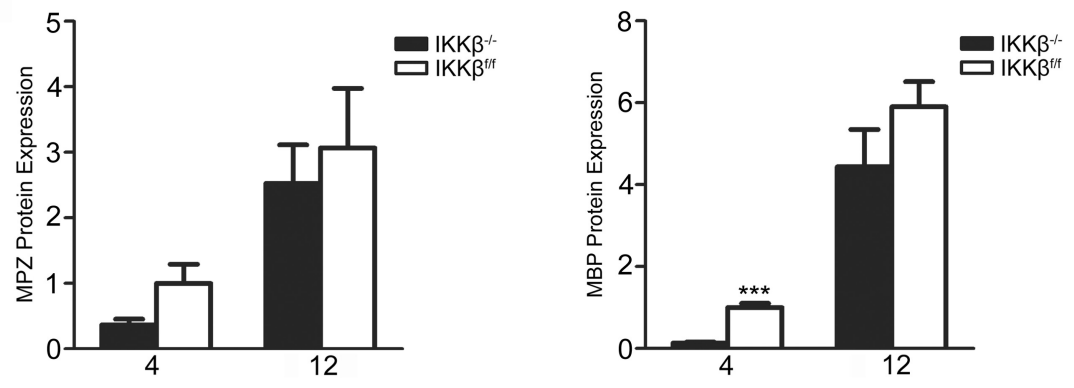

Figure 3. Myelin basic protein expression is transiently reduced in mice lacking IKK $\beta$ expression in Schwann cells. $\boldsymbol{A}$, Immunoblots of MPZ, MBP, and $\beta$-actin (loading control) on protein isolated from sciatic nerves at $p 4$ and $p 12 . n=4$ animals per group; each well represents one animal. $\boldsymbol{B}$, Densitometric quantification of MPZ and MBP protein expression (seen in $\boldsymbol{A}$ ). All three isoforms of MBP were quantified. Data expressed as the mean \pm SEM of 4 animals/group. ${ }^{* *} p<0.001$, unpaired Student's $t$ test $\left(\right.$ IKK $\beta^{-/-}$vs IKK $\left.\beta^{\mathrm{f} / \mathrm{f}}\right)$.

followed by anti-chicken Alexa Fluor 488 (1:750; Invitrogen) for $1 \mathrm{~h}$ at room temperature. For phospho-p65 (p-p65) stains, a TSA kit, with HRP-goat anti-rabbit IgG (Invitrogen) was used, according to manufacturer's instructions, along with a rabbit antibody against p65, phosphoSer276 (1:400; Millipore). Confocal images were acquired on an Olympus FluoView 1000 confocal microscope with a $20 \times$ objective or $63 \times$ oil objective.

Western blot analysis. Mice were anesthetized and sciatic nerves were removed and immediately frozen in liquid nitrogen. Nerve samples were then homogenized in $200 \mu$ l of lysis buffer $(20 \mathrm{mmol} / \mathrm{l} \mathrm{Tris-HCl}, \mathrm{pH} 7.4$, $150 \mathrm{mmol} / \mathrm{l} \mathrm{NaCl}, 1 \%$ Triton X-100, $1 \mathrm{mmol} / \mathrm{l} \mathrm{EDTA}$, and $5 \mathrm{mmol} / \mathrm{l}$ dithiothreitol) containing complete protease inhibitor (Roche) and phosphatase inhibitors (Sigma-Aldrich). Following centrifugation (13,000 $\mathrm{rpm}$ for $20 \mathrm{~min}$ at $4^{\circ} \mathrm{C}$ ), the supernatant was removed and protein concentration was determined with a DC Protein Assay kit (Bio-Rad). Ten micrograms of each protein sample were resolved on a $12 \%$ SDSpolyacrylamide gel by electrophoresis and transferred to a nitrocellulose membrane (Bio-Rad). Membranes were blocked in 5\% bovine serum albumin for $1 \mathrm{~h}$ at room temperature and probed with antibodies against MPZ (chicken, 1:1000; Abcam), MBP (rat, 1:1000; Millipore), and $\beta$-actin (mouse, 1:1000; Sigma-Aldrich). Following overnight incubation at $4^{\circ} \mathrm{C}$ with primary antibodies, membranes were rinsed with TBS-T and incubated with horseradish peroxidase-conjugated anti-chicken (Jackson ImmunoResearch Laboratories), anti-rat (Sigma-Aldrich), or anti-mouse (GE Healthcare) antibodies (1:2000) in 3\% bovine serum albumin at room temperature for $1 \mathrm{~h}$. Proteins were visualized with ECL (GE Healthcare/GE Healthcare) and quantified with Quantity One software (Bio-Rad). Data were normalized against $\beta$-actin and expressed as a percentage of IKK $\beta^{\mathrm{f} / \mathrm{f}}$ postnatal day 4 . A total of 4 animals/group per time point were used.

p-Phenylenediamine and toluidine blue staining. Following transcardial perfusion, sciatic nerves were removed and fixed in $2 \%$ glutaraldehyde/ $0.05 \mathrm{M} \mathrm{PO}_{4} / 100 \mathrm{~mm}$ sucrose. Nerves were then rinsed with $0.15 \mathrm{M}$ phosphate buffer and postfixed in $2 \% \mathrm{O}_{\mathrm{s}} \mathrm{O}_{4} / 0.1 \mathrm{M} \mathrm{PO}_{4}$ for $1 \mathrm{~h}$ at room temperature at the EM core facility in the Miami Project to Cure Paralysis. Tissues were embedded in fresh epoxy resin (Embed, Electron Microscopy Sciences) molds, following dehydration in graded ethanol solutions, and incubated overnight at $64^{\circ} \mathrm{C}$. Semithin $(1 \mu \mathrm{m})$ sections were cut transversely from the proximal portion of the sciatic nerve using a Leica Ultracut E microtome and stained with p-phenylenediamine (PPD) and counterstained with toluidine blue (TB) to visualize myelin. Images were acquired on a Zeiss Axiovert $200 \mathrm{M}$ microscope using a $63 \times$ oil objective and Neurolucida Imaging software.

Morphometric analysis. Using StereoInvestigator software, the following were quantified: average diameter of the sciatic nerve, number of Schwann cell nuclei, number of largediameter axons, and number of compact myelin rings. A $60 \times$ oil objective, fractionater probe, and nucleator probe were used and total population projections of each identifier were compared between IKK $\beta^{\mathrm{f} / \mathrm{f}}$ and IKK $\beta^{-/-}$ littermates.

Statistical analysis. A two-tailed, unpaired Student's $t$ test was used for single comparisons; $p<0.05$ determined significance.

\section{Results}

Characterization of IKK $\boldsymbol{\beta}^{-/-}$mice

To assess the role of NF- $\kappa$ B activation in SC myelination, we crossed MPZ-Cre and IKK $\beta^{\mathrm{f} / \mathrm{f}}$ mice to ablate IKK $\beta$ in SCs. To test the specificity of the MPZ promoter, MPZ-Cre mice were crossed with RO$\mathrm{SA}^{\mathrm{tm} 9}$ reporter mice to visualize Cremediated recombination in SCs within the sciatic nerve (Fig. 1). Cre-recombination occurred in SCs, but not within the brain, of MPZ-Cre-ROSA ${ }^{\mathrm{tm} 9}$ heterozygotes at postnatal day 15 (p15); no tm9 was visible in ROSA ${ }^{\text {tm9 }}$ controls (Fig. 1A).

Since IKK $\beta$ is ubiquitously expressed and fibroblasts constitute a large portion of the sciatic nerve, we isolated SCs from adult sciatic nerves to verify IKK $\beta$ deletion. Immunoblots for IKK $\beta$ from cultured SCs revealed a substantial reduction in IKK $\beta$ immunoreactivity in IKK $\beta^{-1-}$ SCs when compared with IKK $\beta^{\mathrm{f} / \mathrm{f}}$ SCs (Fig. $1 B$ ). Although some IKK $\beta$ was present in IKK $\beta^{-/-}$SCs, it is likely due to residual fibroblast contamination. Since IKK $\beta$ is required for NF- $\kappa \mathrm{B}$ activation, we stained postnatal ( $\mathrm{p} 0$ and $\mathrm{p} 12$ ) sciatic nerves with p-p65 (activated NF- $\kappa \mathrm{B}$ ) to verify the efficacy of our knock-out (Fig. 1C). We were able to detect high p-p65 expression levels in the sciatic nerves of $\mathrm{p} 0 \mathrm{IKK} \beta^{\mathrm{f} / \mathrm{f}}$ mice, a finding in agreement with previous studies (Nickols et al., 2003). No NF$\kappa \mathrm{B}$ activation was detected in $\mathrm{p} 0 \mathrm{IKK} \beta^{-/-}$nerves, indicating functional knockdown of IKK $\beta$. We were unable to detect p-p65 in p12 mouse sciatic nerves in either group. However, we were able to detect a robust NF- $\kappa$ B response $1 \mathrm{~d}$ following sciatic nerve crush injury in the distal segment of sciatic nerves from IKK $\beta^{\mathrm{f} / \mathrm{f}}$ but not IKK $\beta^{-/-}$adult mice (Fig. 1C).

To further verify the efficacy of IKK $\beta$ deletion on the inhibition of NF- $\kappa$ B activation, we isolated and cultured SCs from mice at p8 and p12 (Fig. 1D). SCs were clearly labeled with $S 100 \beta$ on the fourth day in vitro. We saw a significant decrease in p-p65 immunoreactivity in SCs from IKK $\beta^{-l-}$ mice $\left(\mathrm{IKK} \beta^{-l-} \mathrm{p} 8\right.$ : $0.203 \pm 0.028 ; \mathrm{IKK} \beta^{\mathrm{f} / \mathrm{f}} \mathrm{p} 8: 1.000 \pm 0.000 ; \mathrm{IKK} \beta^{-l-} \mathrm{p} 12: 0.057 \pm$ 0.057; IKK $\beta^{\mathrm{f} / \mathrm{f}}$ p12: $1.000 \pm 0.000$ ) (Fig. $\left.1 E\right)$. All SCs in IKK $\beta^{\mathrm{f} / \mathrm{f}}$ mice expressed activated NF- $\kappa \mathrm{B}$ (Fig. $1 D$ ), and there was no significant difference in the total number of Schwann cells between groups (data not shown). Additionally, all other cell types (i.e., fibroblasts) expressed p-p65 in both groups. Together, these data 
suggest that IKK $\beta$ protein function is absent in IKK $\beta^{-1-}$ SCs, which nearly completely ablates NF- $\kappa \mathrm{B}$ activation.

\section{Inhibition of NF- $\kappa$ B activation in Schwann cells transiently delays myelination}

To determine whether NF- $\kappa \mathrm{B}$ activation in SCs is required for myelinogenesis, sciatic nerves were harvested from mice at $\mathrm{p} 4$, p8, p12, and p40 (Fig. 2A). Semithin, transverse, PPD-stained, and TB-stained sections revealed no significant, morphological differences in myelination between IKK $\beta^{-/-}$and control littermates (Fig. $2 B$ ). Both groups displayed similar nerve-trunk diameters (Fig. $2 D)\left(\mathrm{IKK} \beta^{-/-}\right.$p4: $242.2 \pm 3.379 \mu \mathrm{m}$; IKK $\beta^{\mathrm{f} / \mathrm{f}} \mathrm{p} 4$ : $227.0 \pm 4.479 \mu \mathrm{m} ; \mathrm{IKK} \beta^{-l-}$ p8: $267.4 \pm 19.01 \mu \mathrm{m} ; \mathrm{IKK} \beta^{\mathrm{f} / \mathrm{f}} \mathrm{p} 8:$ $285.7 \pm 17.02 \mu \mathrm{m} ; \mathrm{IKK} \beta^{-/-}$p12: $302.2 \pm 14.57 \mu \mathrm{m} ; \mathrm{IKK} \beta^{\mathrm{f} / \mathrm{f}}$ p12: $320.6 \pm 8.442 \mu \mathrm{m})$. There were no differences in the total number of myelin rings (Fig. $2 C$ ) between groups (IKK $\beta^{-1-} \mathrm{p} 4$ : $806.4 \pm 80.18$; IKK $\beta^{\mathrm{f} / \mathrm{f}}$ p4: $689.4 \pm 98.49 ; \mathrm{IKK} \beta^{-1-} \mathrm{p} 8: 1893 \pm$ 358.4; IKK $\beta^{\mathrm{f} / \mathrm{f}}$ p8: $1831 \pm 384.6$; IKK $\beta^{-/-}$p12: $2968 \pm 527.8$; $\mathrm{IKK} \beta^{\mathrm{f} / \mathrm{f}}$ p12: $\left.3616 \pm 243.8\right)$. Immunoblots showed a significant reduction in myelin basic protein (MBP) protein expression levels within the sciatic nerves of IKK $\beta^{-1-}$ mice at $\mathrm{p} 4$, which was attenuated by $\mathrm{p} 12$, when compared with $\mathrm{IKK} \beta^{\mathrm{f} / \mathrm{f}}$ littermates (Figs. 2A,3). There was no significant difference in MPZ protein expression levels within the sciatic nerves of $\mathrm{IKK} \beta^{-1-}$ and $\mathrm{IKK} \beta^{\mathrm{f} / \mathrm{f}}$ mice at $\mathrm{p} 4$ or $\mathrm{p} 12$. Myelin protein expression increased between $\mathrm{p} 4$ and p12 in both groups as myelination ensued (Fig. $3)$. Hence, NF- $\kappa$ B activation is dispensable for myelination and only transiently required for myelin-specific protein expression in vivo.

\section{Discussion}

Here, we show for the first time that NF- $\kappa$ B activation in SCs is not required for myelination in vivo. IKK $\beta$ deletion resulted in a strong suppression of NF- $\kappa \mathrm{B}$ activation at birth and during the developmental time window of ongoing myelinogenesis (Fig. 1). Although we observed a significant decrease in MBP protein expression at $\mathrm{p} 4$ in the absence of IKK $\beta$ (Fig. 2), this effect was quickly attenuated. We were unable to assess NF- $\kappa \mathrm{B}$ activation at $\mathrm{p} 4$ in vitro, due to poor cell viability in both groups. Since NF- $\kappa \mathrm{B}$ activation was greatly ablated in IKK $\beta^{-1-}$ sciatic nerves at birth and in SC cultures isolated at $\mathrm{p} 8$ and $\mathrm{p} 12, \mathrm{NF}-\kappa \mathrm{B}$ activation is likely absent at $\mathrm{p} 4$ in knock-out sciatic nerves. Therefore, during myelinogenesis, NF- $\kappa \mathrm{B}$ is highly active at birth and minimally active by $\mathrm{p} 12$ in mouse sciatic nerves; however, NF- $\kappa \mathrm{B}$ activation is robust in cultured SCs isolated from postnatal nerves.

Although previous findings implicate a role for NF- $\kappa$ B signaling in SC myelin induction in vitro, our results show that NF- $\kappa \mathrm{B}$ activation is unnecessary to achieve myelination in vivo. One possible explanation for the discrepancy between these findings is that SCs behave differently in vivo than in vitro. It was recently shown that NF- $\kappa \mathrm{B}$ activation in SCs is required for timely remyelination following peripheral nerve injury (Morton et al., 2012). Perhaps dissociation of nerve tissue and SC isolation techniques, commonly used to study SCs in vitro, impose/reflect an injury event that alters the typical SC signaling ensued during development. In the context of NF- $\kappa \mathrm{B}$ regulation of myelination, in vitro, immature SCs behave as in vivo, denervated SCs, and do not accurately reflect the signaling mechanisms used by immature SCs in vivo. Hence, in vitro SC myelination does not appear to hinge on the same signaling cascades as SC myelination during perinatal nerve development. SC myelination during development and following injury likely use different transcriptional programs.

\section{References}

Chen Y, Wang H, Yoon SO, Xu X, Hottiger MO, Svaren J, Nave KA, Kim HA, Olson EN, Lu QR (2011) HDAC-mediated deacetylation of NF-kappaB is critical for Schwann cell myelination. Nat Neurosci 14:437-441. CrossRef Medline

Honkanen H, Lahti O, Nissinen M, Myllylä RM, Kangas S, Päiväläinen S, Alanne MH, Peltonen S, Peltonen J, Heape AM (2007) Isolation, purification, and expansion of myelin-competent, neonatal mouse Schwann cells. Eur J Neurosci 26:953-964. CrossRef Medline

Jessen KR, Mirsky R (2005) The origin and development of glial cells in peripheral nerves. Nat Rev Neurosci 6:671-682. CrossRef Medline

Li ZW, Chu W, Hu Y, Delhase M, Deerinck T, Ellisman M, Johnson R, Karin M (1999) The IKKbeta subunit of IkappaB kinase (IKK) is essential for nuclear factor kappaB activation and prevention of apoptosis. J Exp Med 189:1839-1845. CrossRef Medline

Li ZW, Omori SA, Labuda T, Karin M, Rickert RC (2003) IKK beta is required for peripheral B cell survival and proliferation. J Immunol 170: 4630-4637. Medline

Limpert AS, Carter BD (2010) Axonal neuregulin 1 type III activates NFkappaB in Schwann cells during myelin formation. J Biol Chem 285: 16614-16622. CrossRef Medline

Limpert AS, Bai S, Narayan M, Wu J, Yoon SO, Carter BD, Lu QR (2013) NF- $\kappa \mathrm{B}$ forms a complex with the chromatin remodeler BRG1 to regulate Schwann cell differentiation. J Neurosci 33:2388-2397. CrossRef Medline

Manent J, Oguievetskaia K, Bayer J, Ratner N, Giovannini M (2003) Magnetic cell sorting for enriching Schwann cells from adult mouse peripheral nerves. J Neurosci Methods 123:167-173. CrossRef Medline

Morton PD, Johnstone JT, Ramos AY, Liebl DJ, Bunge MB, Bethea JR (2012) Nuclear factor-kappaB activation in Schwann cells regulates regeneration and remyelination. Glia 60:639-650. CrossRef Medline

Nickols JC, Valentine W, Kanwal S, Carter BD (2003) Activation of the transcription factor NF-kappaB in Schwann cells is required for peripheral myelin formation. Nat Neurosci 6:161-167. CrossRef Medline

Ryu EJ, Wang JY, Le N, Baloh RH, Gustin JA, Schmidt RE, Milbrandt J (2007) Misexpression of Pou3f1 results in peripheral nerve hypomyelination and axonal loss. J Neurosci 27:11552-11559. CrossRef Medline

Yoon C, Korade Z, Carter BD (2008) Protein kinase A-induced phosphorylation of the p65 subunit of nuclear factor- $\kappa \mathrm{B}$ promotes Schwann cell differentiation into a myelinating phenotype. J Neurosci 28:3738-3746. CrossRef Medline 